\title{
Hubungan Kadar Matriks Metaloproteinase-2 Serum dan Skor Aspartate To Platelet Ratio Index untuk Menilai Fibrosis Hati antara Penyandang Thalassemia yang Mendapat Terapi Kelasi Besi Deferoksamin dan Deferipron
}

\author{
Asep Aziz Asopari, Dwi Prasetyo, Budi Setiabudiawan \\ Departemen Ilmu Kesehatan Anak Fakultas Kedokteran Universitas Padjadjaran/Rumah Sakit Dr. Hasan \\ Sadikin, Bandung
}

\begin{abstract}
Latar belakang. Penyandang thalassemia secara progresif akan mengalami keadaan kelebihan besi yang dapat menyebabkan terbentuknya peroksidase lipid dan merusak sel hati sehingga terbentuk fibrosis hati. Terapi kelasi besi bertujuan untuk mengurangi kelebihan besi.

Tujuan. Mengetahui hubungan kadar MMP-2 serum dan peningkatan skor APRI untuk menilai fibrosis hati antara penyandang thalassemia yang mendapat terapi kelasi besi deferoksamin dengan deferipron.

Metode. Penelitian potong lintang dilaksanakan dari Juli-Agustus 2013, dilibatkan 42 penyandang thalassemia usia 2,5-14 tahun yang mendapat terapi kelasi besi deferoksamin dan deferipron. Kadar MMP2 serum diperiksa dengan metode ELISA dan perhitungan skor APRI dengan Rumus Wai. Perbedaan dan korelasi ditentukan antara varibel dengan uji Mann-Whitney dan Rank Spearmann. Analisis kovariat digunakan untuk menghilangkan faktor perancu.

Hasil. Terdapat 44 subjek, 22 mendapat terapi kelasi besi deferoksamin dan 22 deferipron. Kadar MMP-2 serum kelompok deferipron lebih rendah $(130 \mathrm{ng} / \mathrm{mL})$ dibandingkan deferoksamin $(314 \mathrm{ng} / \mathrm{mL})$. Skor APRI kelompok deferipron rata-rata lebih tinggi (1,584) dibanding deferoksamin (0,575). Perbedaan skor APRI dan kadar MMP-2 serum kedua kelompok sangat bermakna $(\mathrm{p}<0,001)$. Terdapat korelasi negatif antara kadar MMP-2 serum dan skor APRI, yaitu semakin tinggi skor APRI maka semakin rendah kadar MMP-2 serum penyandang thalassemia yang mendapat terapi kelasi besi deferipron dan deferoksamin $(r=-0,726, p=<0,001)$.

Kesimpulan. Penurunan kadar MMP-2 serum dan peningkatan skor APRI untuk menilai fibrosis hati pada kelompok terapi kelasi besi deferipron lebih tinggi dibandingkan dengan kelompok deferoksamin serta terdapat korelasi negatif antara kadar MMP-2 serum dan skor APRI. Sari Pediatri 2014;16(1):57-63.
\end{abstract}

Kata kunci: fibrosis hati, matriks metaloproteinases-2 serum, skor APRI, thalassemia

\footnotetext{
Alamat korespondensi:

Dr. Dwi Prasetyo, dr. SpA(K), M.Kes. Departemen Ilmu Kesehatan Anak Fakultas Kedokteran Universitas Padjadjaran/Rumah Sakit Dr. Hasan Sadikin. Jl. Pasteur No. 38 Bandung 40163. Tel 022-2035957. Email: dipras2000@yahoo.com
}

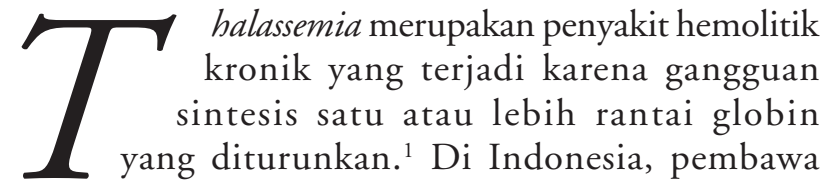


sifat thalassemia berkisar 3\%-10\%. Penyandang thalassemia memerlukan tranfusi darah berulang untuk mempertahankan kadar hemoglobin lebih dari $10 \mathrm{~g} /$ dL. ${ }^{1-4}$ Penimbunan besi karena proses eritropoesis tidak efektif dan tranfusi berulang membentuk nontransferin bound iron (NTBI) dan peroksidase lipid yang dapat menyebabkan kerusakan dan kematian sel hati pada penyandang thalassemia. ${ }^{5-8}$ Keadaan cedera hati yang menetap, regenerasi hati gagal, dan hepatosit disubtitusi matriks ekstraselular (ECM) akan menyebabkan fibrosis hati. ${ }^{9-12}$

Manusia tidak memiliki mekanisme untuk mengekskresi kelebihan besi, diperlukan terapi kelasi yang dapat mengikat zat besi yang berlebih, agar dapat dikeluarkan dari tubuh. ${ }^{13-15}$ Deferoksamin (DFO) dan deferiprone (DFP) merupakan kelasi besi yang sama efektifnya dalam menurunkan kelebihan besi, tetapi deferipron dianggap mempunyai dampak terhadap hati sehingga dapat menyebabkan fibrosis hati. ${ }^{16,17}$

Pemeriksaan petanda langsung (direct marker) dan tidak langsung (indirect marker) proses fibrosis hati dilakukan untuk menilai proses fibrogenesis dan fibrinolisis, serta menghindari biopsi hati sebagai standar baku pemeriksaan biopsi hati. ${ }^{18,20}$ Matriks metaloproteinases-2 (MMP2) serum merupakan glikoprotein yang dapat dipakai untuk menilai proses destruksi dan degradasi ECM. ${ }^{20,21}$ Arikan $\mathrm{dkk}^{21}$ menemukan korelasi berbagai marker fibrosis dengan fibrosis hati pada penderita thalassemia mayor yang mendapat kelasi besi deferasirox. Aspartate aminotransferase to platelet ratio index (skor APRI) diformulasikan oleh Wai dkk ${ }^{22}$ membandingkan kadar aspartat transaminase terhadap trombosit, digunakan untuk untuk menilai fibrosis hati. Shaheen dan Myers ${ }^{23}$ melaporkan skor APRI kurang dari 0,5 memiliki nilai prediktif negatif (negative predictive value/NPV) 86\%, sedangkan pada skor yang lebih besar dari 1,5 memiliki nilai prediktif positif (positive predictive value/PPV) $88 \%$.

Penelitian ini bertujuan untuk mengetahui hubungan kadar MMP-2 serum dan peningkatan skor APRI untuk menilai fibrosis hati antara penyandang thalassemia yang mendapat terapi kelasi besi deferoksamin dengan deferipron.

\section{Metode}

Penelitian analitik komparatif dengan rancangan potong lintang (cross sectional). Pemilihan subjek dilakukan secara berturut-turut (consecutive sampling) sampai jumlah sampel terpenuhi. Subjek penelitian adalah penyandang thalassemia yang mendapat terapi kelasi besi deferoksamin dan deferipron di Poli Thalassemia Anak Rumah Sakit Hasan Sadikin Bandung pada bulan Juli-Agustus 2013. Kriteria inklusi adalah 1) penyandang thalassemia mayor usia 2-4 tahun, 2) Penyandang thalassemia mayor yang mendapat terapi kelasi besi deferoksamin dan deferipron, dan 3) kadar feritin serum $\geq 2500 \mathrm{ng} / \mathrm{mL}$. Variabel bebas/independen adalah penyandang thalassemia yang mendapat deferoksamin dan deferipron. Variabel tergantung/dependen adalah kadar MMP-2 serum dan skor APRI. Variabel perancu adalah usia dan status gizi. Penyandang thalassemia mayor adalah penderita thalassemia yang telah didiagnosis berdasarkan gejala klinis dan pemeriksaan hemoglobin elektroforesis.

Penyandang thalassemia mayor yang memenuhi kriteri inklusi akan dilakukan anamnesis pemeriksaan fisik, status antropometri, dan dilakukan pemeriksaan kada MMP2 serum serta perhitungan skor APRI. Pemeriksaan kadar MMP-2 serum diperiksa dengan menggunakan metode Enzym-linked Imunoabsorbent Assay (ELISA) di laboratorium Patologi Klinik RS Hasan Sadikin Bandung dan skor APRI dihitung berdasarkan rumus Wai, yaitu kadar SGOT dibagi kadar normal SGOT kemudian dibagi kadar trombosit dan dikalikan 100. Analisis statistik untuk data katagorik yang berdistribusi normal dilakukan menggunakan uji t tidak berpasangan dan data yang tidak berdistribusi normal dengan menggunakan uji Mann-Whitney. Analisis korelasi antara kadar MMP2 serum dan skor APRI digunakan analisis korelasi Rank Spearmann. Analisis Kovariat digunakan untuk menyingkirkan faktor perancu. Program statistik yang digunakan adalah SPSS for windows versi 18.0 pada derajat kepercayaan 95\% dengan nilai $\mathrm{p}<0,05$.

Penelitian ini telah mendapat persetujuan Komite Etik Penelitian Kesehatan Fakultas Kedokteran Universitas Padjadjaran/RSUP Dr. Hasan Sadikin Bandung. Persetujuan ikut serta dalam penelitian didapatkan dari orangtua/wali penderita.

\section{Hasil}

Empat puluh dua penyandang thalassemia mayor terdiri atas 17 anak laki-laki dan 27 anak perempuan, 22 penyandang thalasemia mendapat terapi kelapi besi deferoksamin dan 22 mendapat deferipron. Karakteristik subjek penelitian tertera pada Tabel 1. 
Usia rata-rata pada kelompok deferipron lebih muda dibandingkan dengan kelompok deferoksamin dan secara statistik didapatkan perbedaan yang sangat bermakna $(\mathrm{p}<0,01)$. Status gizi sebagian besar subjek normal dan tidak didapatkan perbedaan bermakna $(p>0,05)$ pada kedua kelompok, tetapi sebagian besar mengalami gangguan pertumbuhan linier berupa perawakan pendek stunted dan severly stunted. Kadar kadar feritin serum dan CRP-kuantitatif pada kedua kelompok tidak berbeda secara bermakna $(p>0,05)$.

Perbedaan kadar MMP-2 serum dan skor APRI pada penyandang thalassemia mayor yang mendapat kelasi besi deferoksamin dan deferipron tertera pada Tabel 2.

Nilai median kadar MMP-2 serum kelompok penyandang thalassemia yang mendapat terapi kelasi deferoksamin mempunyai nilai median lebih tinggi dibandingkan kelompok deferipron, tetapi skor APRI penyandang thalassemia yang mendapat deferoksamin lebih rendah dibandingkan dengan kelompok deferipron.

Analisis kovariat digunakan untuk menghilangkan faktor perancu usia pada kedua kelompok. Setelah dilakukan analisis kovariat dengan memasukkan usia terhadap perbedaan kadar MMP-2 serum pada kedua kelompok kelasi besi, didapatkan hasil perbandingan $\log$ MMP-2 serum yang sangat bermakna $(\mathrm{p}<0,01)$. Hasil analisis kovariat untuk skor APRI pada kedua kelompok kelasi besi dengan memasukkan usia sebagai kovariat, didapatkan hasil perbandingan log skor APRI yang sangat bermakna $(\mathrm{p}<0,01)$.

Korelasi kadar MMP-2 serum dan skor APRI penyandang thalassemia yang mendapat terapi kelasi besi deferoksamin dan deferiprone tertera pada Tabel 3.

Korelasi antara kadar MMP-2 serum dengan skor APRI kelompok kelasi besi deferoksamin secara statistik tidak bermakna dengan $r=-0,177$ dan $p<0,431$, sedangkan pada kelompok kelasi besi deferipron terdapat korelasi negatif antara kadar MMP-2 serum dan skor APRI yang secara statistik sangat bermakna dengan $\mathrm{r}=-0,848$ dan $\mathrm{p}<0,001$.

Scatter graph Gambar 1 menunjukkan tidak terdapat korelasi antara kadar MMP-2 serum dan skor APRI penyandang thalassemia yang mendapat kelasi deferoksamin.

Scatter graph Gambar 2 menunjukkan korelasi negatif antara kadar MMP-2 serum dan skor APRI penyandang thalassemia yang mendapat kelasi

Tabel 1. Karakteristik subjek penelitian

\begin{tabular}{|c|c|c|c|}
\hline \multirow{2}{*}{ Karakteristik } & \multicolumn{2}{|c|}{ Kelasi besi } & \multirow[b]{2}{*}{$\mathrm{p}$} \\
\hline & Deferoksamin & Deferipron & \\
\hline \multicolumn{4}{|l|}{ Usia (tahun) } \\
\hline Rata-rata (SB) & $10,68(2,934)$ & $8,8(3,75)$ & \\
\hline Rentang & $4-14$ & $3-14$ & $0,002^{*}$ \\
\hline \multicolumn{4}{|l|}{ Jenis Kelamin } \\
\hline Laki-laki & 7 & 10 & \\
\hline Perempuan & 15 & 12 & $0,353^{* *}$ \\
\hline \multicolumn{4}{|l|}{ Status gizi } \\
\hline Normal (-2 s.d. $2 \mathrm{SD})$ & 19 & 18 & \\
\hline Malnutrisi (<-2SD) & 2 & 3 & $0,507^{* *}$ \\
\hline \multicolumn{4}{|l|}{$\mathrm{TB} / \mathrm{U}$} \\
\hline Normal & 2 & 6 & \\
\hline Stunted & 17 & 14 & $0,208^{* *}$ \\
\hline Severly stunted & 3 & 2 & \\
\hline \multicolumn{4}{|l|}{ Kadar feritin serum } \\
\hline Median & 4,494 & 5110,9545 & $0,307^{*}$ \\
\hline Rentang & $2,500-15,876$ & $2,500-15,876$ & \\
\hline \multicolumn{4}{|l|}{ Kadar CRP serum } \\
\hline Median & 2,1636 & 3,6136 & $0,110^{*}$ \\
\hline Rentang & $0,40-12,9$ & $0,70-12,90$ & \\
\hline
\end{tabular}

Keterangan: )*nilai p setelah dilakukan Uji Mann-Whitney, ${ }^{* *}$ Uji t Test, TB=tinggi badan, U=usia 
Asep Aziz Asopari dkk: Hubungan kadar MMP-2 serum dan skor APRI untuk menilai fibrosis hati penyandang thalassemia terapi kelasi besi DFO dan DFP

Tabel 2. Perbedaan kadar MMP-2 serum dengan skor APRI

\begin{tabular}{lccc}
\hline \multirow{2}{*}{ Variabel } & \multicolumn{2}{c}{ Kelasi besi } & \multirow{2}{*}{$\mathrm{p}$} \\
\cline { 2 - 3 } Kadar MMP-2 serum & Deferoksamin & Deferipron & \\
Median & 314 & 130 & $<0,001$ \\
Rentang & $214-480$ & $89-599$ & \\
& & & \\
Skor APRI & 0,575 & 1,584 & $<0,001$ \\
$\quad \begin{array}{l}\text { Median } \\
\text { Rentang }\end{array}$ & $0,05-1,08$ & $0,18-12,90$ & \\
& & & \\
\hline
\end{tabular}

Keterangan: nilai p berdasarkan Uji Mann-Whitney

Tabel 3. Korelasi kadar MMP-2 serum dengan skor APRI

\begin{tabular}{lcccc}
\hline & \multicolumn{2}{c}{ Deferoksamin } & \multicolumn{2}{c}{ Deferipron } \\
\cline { 2 - 4 } & $\mathrm{r}$ & $\mathrm{p}$ & $\mathrm{r}$ & $\mathrm{p}$ \\
\hline $\begin{array}{l}\text { Korelasi antara kadar MMP-2 } \\
\text { dan skor APRI }\end{array}$ & $-0,177$ & 0,431 & $-0,848$ & 0,001 \\
\hline
\end{tabular}

Keterangan $\mathrm{r}=$ koefisiensi korelasi Rank Spearman

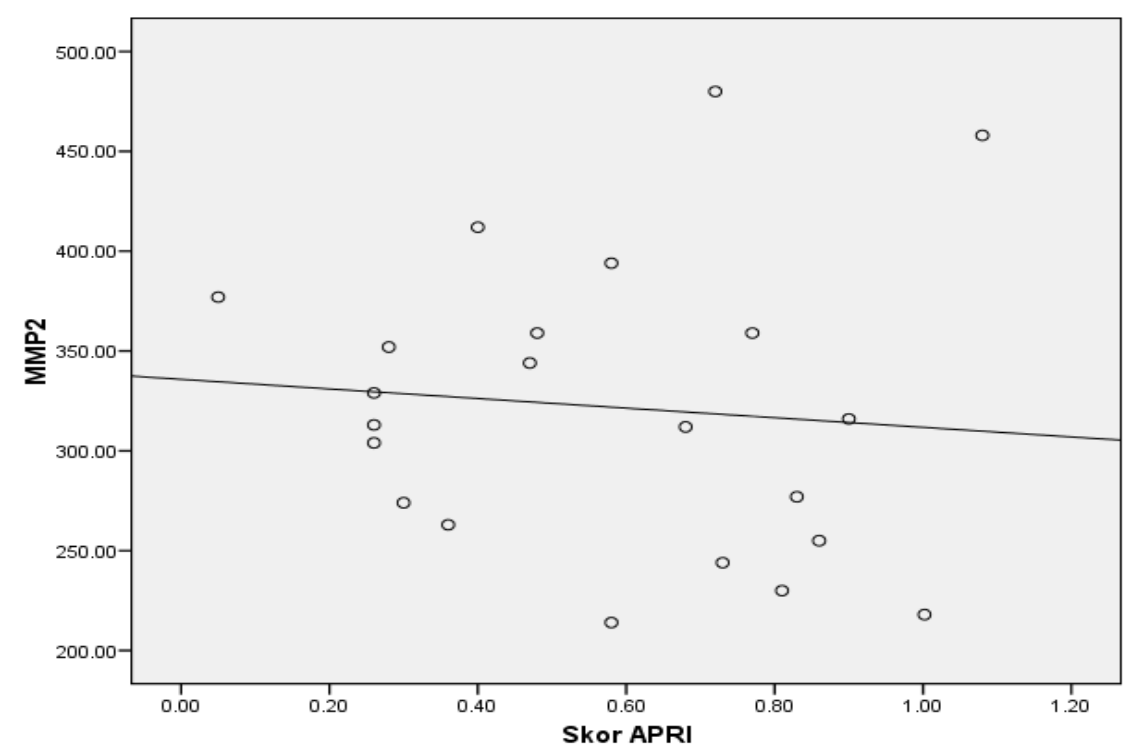

Gambar 1. Korelasi kadar MMP-2 serum dan skor APRI pada penyandang thalassemia yang mendapat deferoksamin

deferipron, yaitu semakin rendah kadar MMP-2 serum semakin tinggi skor APRI.

\section{Pembahasan}

Hasil penelitian ini menunjukkan terdapat perbedaan kadar MMP-2 serum antara penyandang thalassemia yang mendapat terapi kelasi besi deferoksamin dengan kelasi besi deferipron, walaupun setelah dilakukan analisis kovariat untuk menghilangkan usia sebagai faktor perancu. Perbedaan ini terjadi karena mekanisme kerja antara kedua kelasi berbeda dalam ambilan besi di hepatosit. ${ }^{13}$ Molekul hidrofilik deferoksamin mempermudah ambilan besi di hepatosit dibandingkan dengan deferiprone. Metabolisme deferipron dihati untuk membentuk 


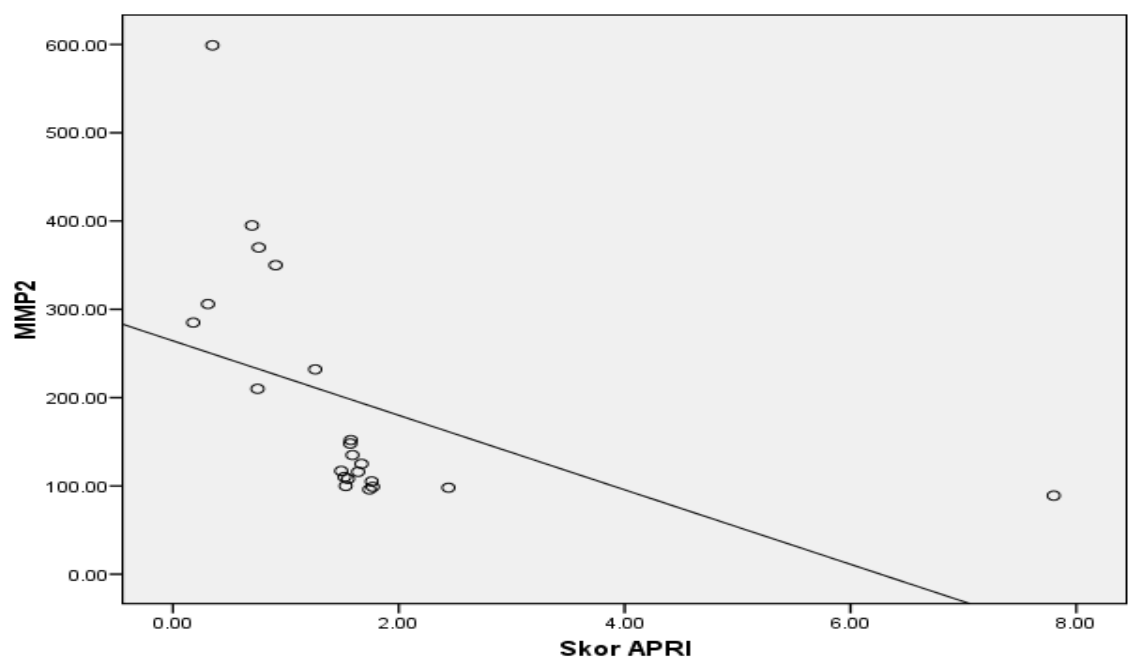

Gambar 2. Korelasi kadar MMP-2 serum dengan skor APRI pada penyandang thalassemia yang mendapat deferipron

glukoronid juga menyebabkan gangguan fungsi hati berupa peningkatan enzim transaminase hati. ${ }^{13-15}$ Proses kelebihan besi yang berlangsung terus menerus menyebabkan pembentukan radikal bebas dan menghasilkan peroksidase lipid. ${ }^{5-8}$ Peroksidase lipid merusak sel hepatosit dan merangsang terbentuknya matriks ekstraselular (ECM). Peningkatan sintesis ECM dan over ekspresi dari tissue inhibitor of metaloproteinases-1 (TIMP-1) serum akan menyebabkan MMP-2 serum menurun. ${ }^{6,24,25}$ Penelitian yang menilai korelasi kadar MMP-2 serum untuk menilai fibrosis hati dengan membandingkan kedua kelasi besi belum pernah dipublikasikan. Brittenham $\mathrm{dkk}^{17}$ menemukan kejadian agranulositosis dan fibrosis hati pada penyandang thalassemia yang mendapat kelasi besi deferipron dibandingkan kelasi besi deferoksamin dengan menggunakan biopsi hati.

Terdapat perbedaan rata-rata skor APRI antara kelompok kelasi besi deferoksamin dengan deferipron, walaupun setelah dilakukan analisis kovariat untuk menyingkirkan usia sebagai faktor perancu. Keadaan ini disebabkan gangguan struktur hati yang terus berlangsung akan mengganggu fungsi hati secara keseluruhan. ${ }^{11,12}$ Kerusakan hepatosit progresif menyebabkan aspartate aminotransferase (AST) dilepaskan ke dalam sirkulasi sehingga kadarnya meningkat pada saat proses kerusakan hati menjadi kronik. ${ }^{27}$ Gangguan pembentukan trombopoetin yang disebabkan gangguan fungsi hati akan menyebabkan proses megakariopoesis dan maturasi trombosit terganggu. ${ }^{27}$

Penelitian yang membandingkan skor APRI pada penyandang thalassemia yang mendapat terapi kelasi besi deferoksamin dengan deferipron belum pernah dipublikasikan. Penelitian skor APRI pada penyandang thalassemia telah dilakukan sebelumnya pada penyandang thalassemia dengan infeksi virus hepatitis C. Penelitian Shaheen dan Myers ${ }^{23}$ menunjukkan skor APRI >1,5 memiliki akurasi yang tinggi untuk menilai fibrosis hati pada penderita hepatitis $\mathrm{C}$ dan dapat meniadakan tindakan biopsi pada sekitar setengah penderita hepatitis C. Pada penelitian ini, penyandang thalassemia yang terinfeksi hepatitis $\mathrm{C}$ dan $\mathrm{B}$ dieksklusi, tetapi mekanisme kerusakan hati akibat kelebihan besi mempunyai mekanisme yang hampir sama dengan proses infeksi. Perbedaan kerusakan hati akibat proses infeksi dan kelebihan besi adalah pada proses infeksi kerusakan sel hati akibat proses inflamasi, sedangkan pada kelebihan besi akibat pembentukkan peroksidase lipid yang merusak sel hati. ${ }^{8-11}$

Tidak terdapat korelasi antara kadar MMP-2 serum dan peningkatan skor APRI penyandang thalassemia yang mendapat terapi kelasi besi deferoksamin. Hasil penelitian ini menunjukan bahwa efektifitas deferoksamin dalam ambilan besi di hepatosit mencegah terjadinya proses kerusakan hati lebih lanjut pada penyandang thalassemia yang mendapat deferoksamin. Penelitian Pennell $\mathrm{dkk}^{28}$ yang menilai efek kelasi besi deferoksamin dan deferipron pada penyandang thalassemia dengan kelainan jantung, menunjukkan ambilan besi di hepatosit lebih baik pada kelasi deferoksamin dibanding kelasi besi deferipron. 
Asep Aziz Asopari dkk: Hubungan kadar MMP-2 serum dan skor APRI untuk menilai fibrosis hati penyandang thalassemia terapi kelasi besi DFO dan DFP

Terdapat korelasi antara kadar MMP-2 serum dan peningkatan skor APRI pada penyandang thalassemia yang mendapat deferipron, yaitu semakin rendah kadar MMP-2 serum maka semakin tinggi skor APRI pada penyandang thalassemia yang mendapat terapi kelasi besi deferipron. Hasil tersebut menunjukkan proses fibrogenesis menyebabkan akumulasi ECM, menurunkan aktifitas MMP-2 serum sehingga kerusakan hati menjadi lebih progresif. ${ }^{10,11,24,25}$ Penelitian tentang korelasi antara MMP-2 serum dan skor APRI belum pernah dipublikasikan. Penelitian sebelumnya menilai korelasi antara asam hialuronik dan Hepaskor menunjukan korelasi yang sangat bermakna pada penyandang thalassemia dengan fibrosis hati. $^{28}$

\section{Kesimpulan}

Penurunan kadar MMP-2 serum dan peningkatan skor APRI untuk menilai fibrosis hati pada penyandang thalassemia mayor yang mendapatkan terapi kelasi besi deferipron lebih tinggi dibandingkan dengan yang mendapat deferoksamin serta terdapat korelasi negatif antara kadar MMP-2 dan skor APRI pada penyandang thalassemia yang mendapat terapi kelasi besi deferoksamin dan deferipron.

\section{Daftar pustaka}

1. Wcatherall DJ. The thalassemias. Dalam: Beutler E, Lichtman M, Coller B, Kipps T, penyunting. Williams hematology. Edisi ke-7. New York: McGrawn-Hill; 2007.h.547-80.

2. Cohen AR, Galanello R, Pennell DJ, Cunningham NJ, Vichinsky E. Thalassemia. Haematology 2004;121:1434.

3. Rund D, Rachmilewitz E. B-thalassemia. N Engl J Med 2005;353:1135-46.

4. Naingolan IM, Harahap A, Liliani RV, Setianingsih I. Alpha thalassemia in Indonesia: moleculer defect and hematologic feature base on population and studies. Presentasi Poster pada Simposium Indonesia_Italy Meeting: Future Trends in Molecular Medicine, 2003.

5. Wright TI, Brissot P. Characterization of non trasferinbound iron clearance by rat liver. J Biol Chem 1986;261:10909-14.

6. McCord JM. Iron, free radicals and oxsidative injury.
Semin Hematol. 1998;35:5-12.

7. Bacon BR, Travill AS, Brittenham GM. Hepatic livid peroxidation in vivo in rats with chronic iron overload. J Clin Invest 1983;71:429-39.

8. Sharma BK, Bacon BR. Britton RS. Prevention of hepatocyt injury and livid peroxidation by iron overload. Gastroenterology 1993;105:1134-40.

9. Ramon B, Daud AB. Liver fibrosis. J Clin Invest 2005;115:209-18.

10. Walace K, Burt AD, Wirght MC. Liver fibrosis. Biochemical J 2008;411:1-8.

11. Friedman SL, Rockey DC, Bissel DM. Hepatic fibrosis. Hepatology 2007;45:242-9.

12. Arthur MPJ. Fibrogenesis. Am J Gastrointest Liver Physiol 2000;27:245-9.

13. Beutler E, Hoffbrand AV, Cook JD. Iron chelation therapy. Review. Hematology Am Soc. Hematol Educ Program 2003;203:40-61.

14. Franchini $M$, Venneri D. Iron chelation therapy: an update. Haematol J 2004;5:287-92.

15. Herskho C. Role of iron chelations therapy in thalassemia major. Turk J Haematol 2002;19:121-6.

16. Gabbuti V, Piga A. Results of long-term iron-chelating theraphy. Acta Haematologica 1996;95:26-36.

17. Brittenham GM, Nathan DG, Olivieri NF, Porter JB, Pippard M, Vichinsky EP, dkk. Deferipron and hepatic fibrosis. Blood 2003;101:5089-91.

18. Rockey DC, Bissel DM. Non invasive measures of liver fibrosis. Hepatology 2006;43:113-20.

19. Myers RP. Non-invasive markers of liver fibrosis: playing the probabilites. Liver International ISSD 2008;56:1328-31.

20. HanYuan-Ping. Matrix metaloproteinasease, the pros and cons, in liver fibrosis. J Gastroenterol Hepatol 2006;21:S88-91.

21. Arikan C, Nart D, Karakas Z, Sasmaz H, Canatan D, Agaoglu L, dkk. Relationship among cellular fibrosis markers and iron concentration and stage of fibrosis in the liver of beta thalassemia patients with tranfusional iron overload. 12 th International Conference on Thalassemia and other hemoglobinopathies, 2011.

22. Wai CT, Greenson JL, Fontana RJ. A simple noninvasive index can predict both significant fibrosis and cirrhosis in patient with chronic hepatitis C. Hepatology 2003;38:518-26.

23. Shaheen AA, Myers RP. Diagnostic accuracy of the aspartateaminotransferase-to-platelet ratio index for the prediction of hepatitis C-related fibrosis: a systematic review. Hepatology 2007;46:912-21. 
Asep Aziz Asopari dkk: Hubungan kadar MMP-2 serum dan skor APRI untuk menilai fibrosis hati penyandang thalassemia terapi kelasi besi DFO dan DFP

24. HanYuan-Ping. Matrix metaloproteinasease, the pros and cons, in liver fibrosis. J Gastroenterol Hepatol 2006;21:S88-91.

25. Arikan C, Nart D, Karakas Z, Sasmaz H, Canatan D, Agaoglu L, dkk. Relationship among cellular fibrosis markers and iron concentration and stage of fibrosis in the liver of beta thalassemia patients with tranfusional iron overload. 12 th International Conference on Thalassemia and other hemoglobinopathies, 2011.

26. Wanless IR, Sweeney G, Dhillon AP, Guido M, Piga A, Galanello R, dkk. Lack of progressive hepatic fibrosis during long-term terapy with deferipron in subjeck with transfusional dependent beta-thalassemia. Blood
2002;100:1566-9.

27. Goulis J. Chau TN, Jordan S, Metha Ab, Watkinson A, Rolles K, dkk. Trombopoetin concentration are low in pathient with cirrhosis and trombositopenia and after orthopic liver transplantation. Gut 1999;44:754-8.

28. Pennell DJ, Berdouka V, Karagiogra M, Ladis VV, Piga A. Randomized controlled trial of deferipron or deferoksamine in beta thalassemia major patients with asytomatic myocardial siderosis. Blood 2006;107:3738-44.

29. Papastamaki M, Delaporta P, Premetis E, Kattamis A, Ladis V, Papassotiriou I. Evaluation of liver fibrosis in patient with thalassemia: the important role of hyalurinic acid. J Bcmd 2010:45;215-8. 